\title{
OBSERVATIONS ON BLOOD GROUP DISTRIBUTION IN PEPTIC ULCER PERFORATION AND GASTRIC PERFORATION
}

\author{
Sureshkumar $B^{1}$, R. Rajavelu², V. Udhayasankar ${ }^{3}$ \\ ${ }^{1}$ Assistant Professor, Department of General Surgery, Government Vellore Medical College, Vellore. \\ 2 Professor, Department of General Surgery, Government Vellore Medical College, Vellore. \\ 3Junior Resident, Department of General Surgery, Government Vellore Medical College, Vellore.
}

\begin{tabular}{l}
\hline ABSTRACT \\
BACKGROUND \\
Aim of this study is to establish and determine the relationship between the A, B, O blood groups' association with complicated \\
peptic ulcer.
\end{tabular}

\section{MATERIALS AND METHODS}

This retrospective study was conducted in a tertiary care centre, Government Vellore Medical College Hospital, on patients who underwent emergency laparotomy for complicated peptic ulcer and gastric perforation from January 2011 to January 2016 . One hundred and seventy two (172) male patients were enrolled in the study. And data was collected based on Age wise and Blood group wise distribution of duodenal ulcer perforation and gastric perforation.

\section{RESULTS}

In 172 patients, all patients were male. In patients with duodenal ulcer perforation, the 0 blood group association was $45.39 \%$ followed by A $36.84 \%$. In patients with gastric perforation, the association with A blood group was $70 \%$, followed by 0 group $20 \%$. The age of the patients ranged from 11 to 90 years. The incidence of duodenal ulcer perforation was highest in the age group of 3140 years (31.57\%), followed by $41-50$ years (23.68\%). The highest incidence of duodenal ulcer perforation occurs in Positive group, 141 individuals $(92.76 \%)$. In gastric perforation, highest incidence was seen in positive group individuals 19 patients (95\%).

\section{CONCLUSION}

After interpretation of the data in the study, it was concluded that

1. Gastric perforation was more common in the blood group A.

2. Duodenal ulcer perforation was common in blood group 0 , followed by blood group A.

3. The incidence of perforation was highest in the age group of 31-40 years.

4. Incidence of gastric perforation was highest in the age group of 61-70 years.

5. Highest incidence of duodenal ulcer perforation as well as gastric perforation was seen in $\mathrm{Rh}$ positive individuals $(92.76 \%$, 95\%).

\section{KEYWORDS}

Complicated Peptic Ulcer; A, B, O Blood Groups; Gastric Perforation.

HOW TO CITE THIS ARTICLE: Sureshkumar B, Rajavelu R, Udhayasankar V. Observations on blood group distribution in peptic ulcer perforation and gastric perforation. J. Evolution Med. Dent. Sci. 2016;5(96):7060-7063, DOI: 10.14260/jemds/2016/1597

\section{BACKGROUND \\ The distribution of the $\mathrm{A}, \mathrm{B}, \mathrm{O}$ blood groups varies in populations throughout the world. In addition to clinical significance for transfusion and transplantation, it is becoming increasingly apparent that A, B, O antigens are of biological significance and may be associated with predisposition to, or protection from many. The A, B, O phenotype has been linked with stomach ulcers, which are more common in group $\mathrm{O}$ individuals and gastric cancer, which is more common in group A individuals. 1,2,3}

Financial or Other, Competing Interest: None.

Submission 09-11-2016, Peer Review 22-11-2016,

Acceptance 24-11-2016, Published 01-12-2016.

Corresponding Author:

Dr. R. Rajavelu,

Professor

Department of General Surgery,

Government Vellore Medical College Hospital,

Adukamparai, Vellore-632011

Tamilnadu

E-mail: rvstanley@gmail.com

DOI: $10.14260 /$ jemds/2016/1597
Duodenal ulcers (DU) may occur in any age group but are most common in the young and middle-aged (20 to 45 years).

They appear in men more often than women. About $95 \%$ of duodenal ulcers are situated within $2 \mathrm{~cm}$ of the pylorus, in the duodenal bulb (cap). Duodenal ulcer is a very common disease in the southern part of India, even though the incidence is decreasing, the complication like perforation is still common and surgical intervention is considered the treatment of choice.

Perforation of gastric or duodenal ulcer is one of the most serious and most overwhelming catastrophic that is affecting human being. Among abdominal emergencies, perforations of peptic ulcer are third in frequencies, acute appendicitis and acute intestinal obstruction being more common. Prompt recognition of the condition is very important and only by early diagnosis and treatment it is possible to reduce the relatively high mortality.1,2,3

The aim of this study was to determine and establish the association between distributions of A, B, O blood groups in patients with complicated duodenal perforation. 


\section{MATERIALS AND METHODS}

A retrospective study was done on patients for the period covering from January 2011 to January 2016 in Government Vellore Medical College and Hospital. One hundred and seventy two (172) male patients were enrolled in the study. Relevant data was collected from hospital registers from emergency cases and from the case sheet records.

\section{The Data was Categorised into Two Groups}

1. Blood group wise distribution of duodenal and gastric perforation.

2. Age wise distribution of duodenal and gastric perforation.

In our study, all the patients underwent emergency laparotomy through a midline incision, by corresponding duty surgeons. All the patients had associated fluid collection. The collected fluid ranges from $200 \mathrm{~mL}$ to 2 litres. Fibrinous flakes were usually present near the perforation and over the loops of intestine.

The size of the perforations ranged from $5 \mathrm{~mm}$ to $2 \mathrm{~cm}$. In operative treatment, all the patients had Graham's repair of the perforation with a pedicled greater omentum applied directly over the perforation and sutured with 2-0 Vicryl and a thorough normal saline wash of the entire peritoneal cavity done with suction of the fluid; 2 drains were placed on either flank for the fluid to come out and to observe for any postoperative leak from the perforation site, and the drains were removed on day five.

The number of patients for whom the data was collected and the sources of the material are shown in Table 1 and table 2 .

\begin{tabular}{|c|c|c|}
\hline $\begin{array}{c}\text { Blood } \\
\text { Group }\end{array}$ & $\begin{array}{c}\text { Duodenal Ulcer } \\
\text { Perforation }\end{array}$ & $\begin{array}{c}\text { Gastric } \\
\text { Perforation }\end{array}$ \\
\hline A & 56 & 14 \\
\hline B & 25 & 2 \\
\hline 0 & 69 & 4 \\
\hline AB & 2 & 0 \\
\hline \multicolumn{2}{|c|}{$\begin{array}{c}\text { Table 1. Blood Group wise Distribution } \\
\text { of Duodenal and Gastric Perforation }\end{array}$} \\
\hline
\end{tabular}

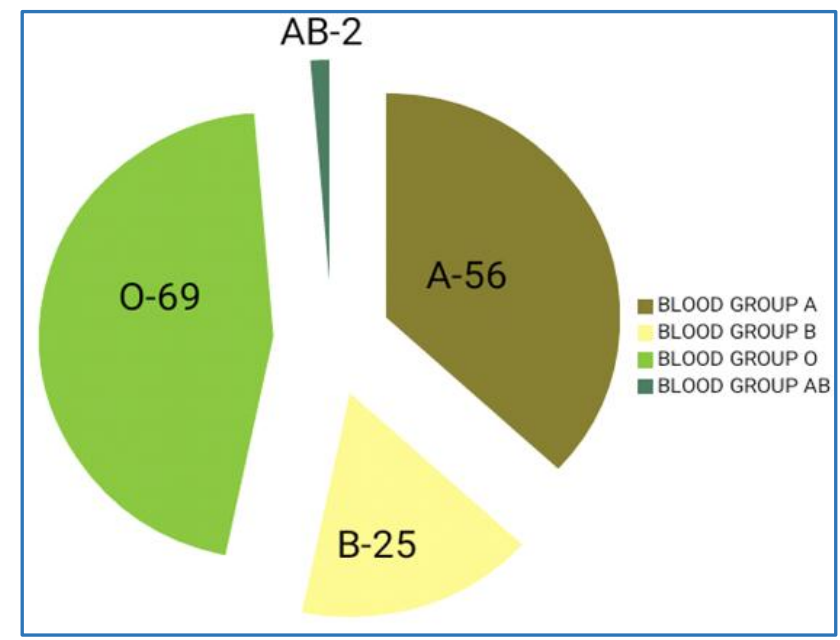

Figure 1. Blood Group wise Distribution of Duodenal Perforation

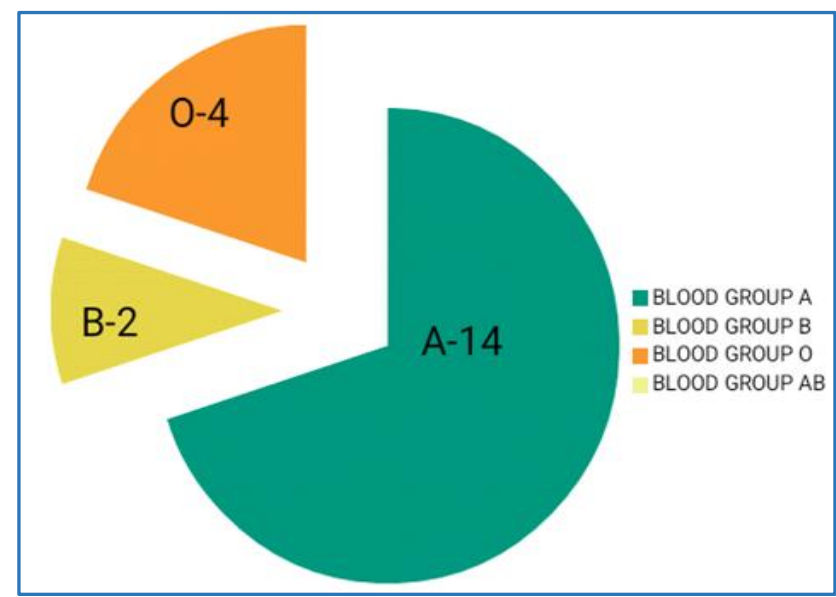

Figure 2. Blood Group wise Distribution of Gastric Perforation

\begin{tabular}{|c|c|c|}
\hline $\begin{array}{c}\text { Age } \\
\text { Distribution }\end{array}$ & $\begin{array}{c}\text { Duodenal } \\
\text { Perforation }\end{array}$ & $\begin{array}{c}\text { Gastric } \\
\text { Perforation }\end{array}$ \\
\hline $11-20$ & - & - \\
\hline $21-30$ & 32 & - \\
\hline $31-40$ & 48 & - \\
\hline $41-50$ & 36 & 4 \\
\hline $51-60$ & 17 & 6 \\
\hline $61-70$ & 7 & 5 \\
\hline $71-80$ & 7 & 3 \\
\hline$>80$ & 5 & \\
\hline Table 2. Age wise Distribution of Duodenal \\
and Gastric Perforation
\end{tabular}

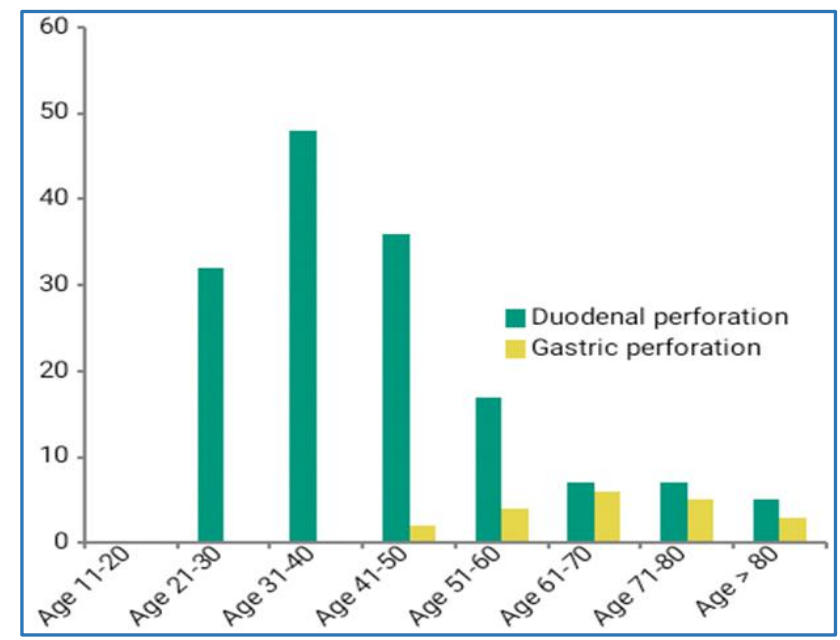

Figure 3. Age wise Distribution of Duodenal and Gastric Perforation

\begin{tabular}{|c|c|c|}
\hline Rh & $\begin{array}{c}\text { Duodenal Ulcer } \\
\text { Perforation }\end{array}$ & $\begin{array}{c}\text { Gastric } \\
\text { Perforation }\end{array}$ \\
\hline Positive & 141 & 19 \\
\hline Negative & 11 & 1 \\
\hline \multicolumn{2}{|c|}{ Table 3. Rh Association with Duodenal } \\
Ulcer Perforation and gastric Perforation
\end{tabular}

\section{RESULTS}

The study consisted of one hundred and seventy two (172) male patients of peptic ulcer perforation. All 172 patients had emergency exploratory laparotomy for the peptic ulcer perforation. 
The table 1 depicts the distribution of $\mathrm{A}, \mathrm{B}, \mathrm{O}$ blood groups in patients with duodenal ulcer perforation and gastric perforation.

In patients with duodenal ulcer perforation, the 0 blood group association was $45.39 \%$, followed by A $36.84 \%$, B $16.44 \%$ and $A B 1.3 \%$. In patients with gastric perforation, the association with A blood group was $70 \%$, followed by 0 group $20 \%$ and then B group $10 \%$.

Table 2 depicts age of the patients ranging from 11 to 90 years. The incidence of duodenal ulcer perforation was highest in the age group of 31-40 years (31.57\%), followed by 41-50 years $(23.68 \%)$ and in $21-30$ yrs. $(21.05 \%)$. These $21-$ 50 years potential productive age group comprises of almost $2 / 3^{\text {rd }}$ of the patients in duodenal ulcer perforation.

Most of the patients belong to the lower socioeconomic group and were illiterate or semiliterate.

Table 3 depicts association $\mathrm{Rh}$ with duodenal ulcer perforation and gastric perforation. The highest incidence of duodenal ulcer perforation occurs in Positive group i.e. 141 individuals (92.76\%). In gastric perforation also, highest incidence was seen in positive group individuals i.e. 19 patients (95\%).

Among the patients in our study, it was noted from the study that patients of blood group A had higher incidence of gastric perforation and patients of blood group 0 had higher incidence $(45.39 \%)$ of duodenal perforation. But it was also noted that patients with blood group A had $36.84 \%$ incidence of duodenal ulcer perforation. The $p$ value is $>0.05$, not significant.

Among the patients in our study, duodenal ulcer perforation was highest in the age group of 31-40 years. The youngest patient was 21 years and the oldest was 84 years of age. It was found that perforated peptic ulcer was very common in the fourth decade of life. They have reasoned it to the increased alcohol intake among the males, because alcohol causes damage to the intestinal mucosa, and also the stress, work burden, but no specific identifiable cause was delineated in the particular age group.

\section{DISCUSSION}

The relationship between blood group 0 and peptic ulcer was proposed initially by Alexander in 1921 . This first proposition led to various researches being conducted on this very association. ${ }^{1}$

Number of research studies showed that the 0 blood group associated with duodenal ulcer.

The research work done by Aird and colleagues showed that people with blood group 0 are $35 \%$ more likely to be diagnosed with peptic ulcer than those with other blood types. ${ }^{4}$

The results of the work done by Roberts et al also showed that the incidence of duodenal ulcer was 1.38 times more common in people belonging to blood group 0 as compared to other blood groups. The researcher believed that duodenal ulcer is $40 \%$ more common in people with blood group 0 as compared to other blood groups. ${ }^{3}$

The researchers at start thought that patients with blood group 0 might be producing the large amount of Hydrochloric acid than others. ${ }^{5}$

Later it was found that in people with blood group 0 , there was increased binding of Helicobacter pylori to the epithelial cells. ${ }^{6}$ It was concluded that denser colonisation of epithelial cells and increased inflammatory reactions as a result of bacterial binding in group 0 people might be one reason that this population is more prone.7,8

Mechanism of this association showed that serum pepsinogen level was found to be greater for individuals with blood type $O$ than blood type $A$. It is believed that the variation in quantity of serum pepsinogen is in relation to the size of gastric secretory cell mass. ${ }^{9}$

It is hypothesised that blood group culminates the development of secretory cell mass, reinforcing that gastric peptic cell mass is larger in group 0 . This might be one of the reasons why blood group 0 is more susceptible to ulcers. ${ }^{7}$

And also Blood group 0 individuals express a higher inflammatory responses with higher levels of lymphocyte infiltration in GI mucosa, a lower level of Von Willebrand's factor, and higher frequency of secretor status. In addition, they didn't produce the substance in surface cells that may protect the lining of the duodenum. These factors altogether demonstrate that blood Group 0 individuals had increased susceptibility to peptic ulceration. ${ }^{10}$

According to that $\mathrm{A}, \mathrm{B}, \mathrm{O} / \mathrm{Rh}$ blood groups, mainly $\mathrm{O}+\mathrm{ve}$ play an important role in patients with peptic ulcer disease. This study is conducted to correlate the association of blood group and peptic ulcer disease.

After interpretation of the data in the study, it reveals that gastric perforation was more common in the blood group $\mathrm{A}$, duodenal ulcer perforation was common in blood group 0 , followed by blood group A.

The incidence of perforation was highest in the age group of 31-40 years in duodenal ulcer perforation, in gastric perforation it was highest in the age group of 61-70 years.

\section{CONCLUSION}

172 cases of peptic ulcer perforation were studied.

1. Gastric perforation was more common in the blood group A.

2. Duodenal ulcer perforation was common in blood group 0 , followed by blood group $\mathrm{A}$.

3. The incidence of perforation was highest in the age group 31-40 years.

4. Incidence of gastric perforation was highest in the age group 61-70 years.

5. Highest incidence of duodenal ulcer perforation as well as gastric perforation seen in $\mathrm{Rh}$ Positive Individuals (92.76\%, 95\%).

6. In this study, all patients were male.

The $\mathrm{p}$ value between blood group A and blood group 0 was $>0.05$ which was not significant. The study needs to be in large volume centres with meta-analysis of data for further correlation of association of blood groups with complicated peptic ulcer.

\section{REFERENCES}

1. Clarke CA. Correlations of A, B, O blood groups with peptic ulcer, cancer, and other diseases. Am J Hum Genet 1959;11(2 pt 2):400-4.

2. Clark CA, Edwards JW, Haddock DRW, et al. A, B, O blood groups and secretor character in duodenal ulcer. BMJ 1956;2(4995):725-31.

3. Roberts JA. Blood groups and susceptibility to disease: a review. Br J Prev Soc Med 1957;11(3):107-25.

4. Aird I, Bentall HH, Mehigan JA, et al. The blood groups in relation to peptic ulceration and carcinoma of colon, 
rectum, breast, and bronchus; an association between the $\mathrm{A}, \mathrm{B}, \mathrm{O}$ groups and peptic ulceration. $\mathrm{Br}$ Med J 1954;2(4883):315-21.

5. Johnson HD, Love AH, Rogers NC, et al. Gastric ulcers, blood groups, and acid secretion. Gut 1964;5:402-11.

6. Jaff MS. Relation between A, B, O blood groups and helicobacter pylori infection in symptomatic patients. Clin Exp Gastroenterol 2011;4:221-6.

7. Borén T, Falk P, Roth KA. Attachment of Helicobacter pylori to human gastric epithelium mediated by blood group antigens. Science 1993;262(5141):1892-95.
8. Kanbay M, Gur G, Arslan H, et al. The relationship of A, B, 0 blood group, age, gender, smoking, and helicobacter pylori infection. Dig Dis Sci 2005;50(7):1214-7.

9. Hanley WB. Hereditary aspects of duodenal ulceration: serum-pepsinogen level in relation to $\mathrm{A}, \mathrm{B}, \mathrm{O}$ blood groups and salivary $\mathrm{ABH}$ secretor status. $\mathrm{Br}$ Med J 1964;1(5388):936-40.

10. Alkout AM, Blackwell CC, Weir DM. Increased inflammatory responses of persons of blood group 0 to helicobacter pylori. J Infect Dis 2000;181(4):1364-9. 